\title{
Faktor-Faktor yang Berhubungan dengan Perilaku Deteksi Dini Kanker Serviks Metode Inspeksi Visual Asam Asetat (IVA) pada WUS di Puskesmas Kecamatan Matraman Jakarta Timur
}

\author{
Factors Related to The Early Detection Of Cervical Cancer \\ Behavior Visual Acetate (IVA) Acid Inspection Methods in \\ WUS in The Puskesmas Matraman District, East Jakarta
}

\author{
Rupdi Lumban Siantar \\ Program Studi D III Kebidanan Medistra \\ Email : rupdie63@yahoo.co.id
}

\begin{abstract}
ABSTRAK
Lebih dari $70 \%$ penderita kanker serviks datang dalam stadium lanjut sehingga banyak menyebabkan kematian karena terlambat ditemukan dan diobati. Oleh karena itu, skrining kanker serviks berupa tes Inspeksi Visual Asam Asetat (IVA) sangat disarankan oleh pemerintah. . Namun hanya 5\% wanita di negara berkembang, termasuk Indonesia, yang menjalani pemeriksaan tersebut. Melihat hal tersebut, penelitian ini dilakukan bertujuan untuk mengetahui faktor- faktor yang berhubungan dengan perilaku deteksi dini kanker serviks pada wus metode IVA. Desain penelitian ini adalah studi case control. Populasi yang diteliti adalah wanita usia subur yang melakukan pemeriksaan ke poliklinik KIA/KB Puskesmas Matraman. Dengan metode quota sampling, diperoleh sampel sebanyak 110 orang. Seluruh data dikumpulkan melalui diwawancarai dengan menggunakan kuesioner. Analisis regresi logistik multivariat digunakan. Setelah dilakukan control terhadapa faktor confounding, Penelitian ini menunjukkan faktor yang berhubungan signifikan dengan Perilaku Deteksi Dini Kanker Serviks metode IVA adalah keterpaparan informasi dengan $\mathrm{AOR}=15,704(95 \% \mathrm{CI}: 4.587$ - 49.544) dan dukungan suami/keluarga dengan AOR = 21,379 (95\%CI : 5.444 - 74.356). Dukungan Suami/Keluarga merupakan faktor dominan dalam Perilaku Deteksi Dini Kanker Serviks Metode IVA. Oleh karena itu, perlu dilakukan upaya untuk meningkatkan frekuensi penyuluhan yang melibatkan keluarag dan suami.
\end{abstract}

Kata Kunci: Faktor risiko, IVA, deteksi dini, kanker serviks

\section{ABSTRACT}

More than $70 \%$ cervical cancer patients come in an advanced stage therefore many cause lead to death by its late diagnosed and treated. For that reason, cervical cancer screening, a visual inspection with acetic acid (IVA), is suggested by the government. But only $5 \%$ women in developing countries, including Indonesia, who did it. Because of that, this study was conducted to identify factors that associated with early detection behavior in cervical cancer prevention. The design of this study is case control. Study population is reproductive aged woman who become patient in family planning services. With the quota of sampling, sample is 110. Data collected through interviewed using a questionnaire. Data analyzed with the logistic regression analysis. After controlled the confounding factors, this study shows early detection behavior is significantly associated with exposed information about early detection with AOR $=15,704$ (95\% CI: 4.587 - 49.544) and husband or family support with AOR =21,379 (95\% CI: 5.444 - 74.356 ). Husband or family support is the dominant factor for early detection of cervical cancer. Therefore, an education to woman and her husband or family is needed

Keywords: Risk factors, IVA, the behavior of early detection of cervical cancer 


\section{PENDAHULUAN}

Kanker serviks merupakan penyebab kematian tertinggi kedua di Indonesia setelah kanker payudara (Rasjidi, 2010). Diperkirakan kematian akibat kanker serviks akan terus meningkat $25 \%$ dalam kurun waktu 10 Tahun mendatang jika tidak dilaksanakan tindakan dan penatalaksanaan yang adekuat (Rasjidi, 2010).

Lebih dari $70 \%$ penderita kanker serviks datang dalam stadium lanjut sehingga banyak menyebabkan kematian karena terlambat ditemukan dan diobati (Nuranna, 2008). Semakin tinggi stadium kanker serviks ditemukan makin sedikit penderita dapat bertahan hidup. Survei penelitian terhadap 11.945 orang penderita kanker serviks ditemukan bahwa probabilitas ketahanan hidup 5 tahun mencapai 95,1\% - 80,1\% untuk stadium I; 66,363,5\% untuk stadium II, 38,7$33,3 \%$ untuk stadium III dan $17,1-9,4 \%$, stadium IV. Oleh karena itu, skrining kanker serviks berupa tes Inspeksi Visual Asam Asetat (IVA) dan pap smear sangat disarankan oleh pemerintah.

Wright (2003) memperkirakan 40\% - 50\% wanita di negara maju pernah melaksanakan skrining. Namun hanya 5\% wanita di negara berkembang, termasuk Indonesia, yang menjalani pemeriksaan. Dengan demikian, banyak kasus kanker serviks ditemukan pada stadium lanjut yang seringkali menyebabkan kematian.

Hal ini disebabkan karena tingkat kesadaran perempuan Indonesia akan bahaya kanker serviks dan untuk melakukan deteksi dini kanker servikss secara teratur masih rendah. Selain itu, faktor lainnya adalah rasa malu serta takut akan hasil pemeriksaan IVA. Pasien sering merasa takut dan kehilangan semangat hidup ketika mengetahui dirinya menderita penyakit kanker karena pendapat umum bahwa kanker tidak bisa diobati dan selalu dihubungkan dengan kematian (Evennet, 2004). Disamping itu, beragam faktor juga diduga berhubungan dengan keberhasilan upaya program deteksi dini kanker serviks antara lain faktor predisposisi (umur, pendidikan, paritas, alat kontrasepsi, pengetahuan, sikap, status perkawinan); faktor pemungkin (sarana dan prasarana serta jarak tempat layanan); dan faktor penguat (jumlah, sikap dan perilaku/ dukungan keluarga, teman, petugas kesehatan).

Berdasarkan uraian tersebut, penelitian

Tabel 1. Karakteristik Responden

\begin{tabular}{|c|c|c|}
\hline Variabel & $\mathbf{n}$ & $\%$ \\
\hline \multicolumn{3}{|c|}{ Deteksi Dini Metode IVA } \\
\hline Ya & 46 & 41.8 \\
\hline Tidak & 64 & 58.2 \\
\hline \multicolumn{3}{|l|}{ Umur } \\
\hline Muda & 72 & 65,5 \\
\hline Tua & 38 & 34.5 \\
\hline \multicolumn{3}{|l|}{ Pendidikan } \\
\hline Rendah & 27 & 24,5 \\
\hline Tinggi & 83 & 75,5 \\
\hline \multicolumn{3}{|l|}{ Pengetahuan } \\
\hline Tinggi & 78 & 70,9 \\
\hline Rendah & 32 & 29,1 \\
\hline \multicolumn{3}{|l|}{ Paritas } \\
\hline Multipara & 66 & 60,0 \\
\hline Primipara & 44 & 40,0 \\
\hline \multicolumn{3}{|c|}{ Jenis Alat Kontrasepsi } \\
\hline Non Hormonal & 47 & 42,7 \\
\hline Hormonal & 63 & 57,3 \\
\hline \multicolumn{3}{|c|}{ Jarak Pelayanan Kesehatan } \\
\hline Dekat & 70 & 63,6 \\
\hline Jauh & 40 & 36.4 \\
\hline \multicolumn{3}{|c|}{ Keterpaparan informasi } \\
\hline Kurang & 49 & 44.5 \\
\hline Baik & 61 & 55.5 \\
\hline \multicolumn{3}{|l|}{ Dukungan Suami } \\
\hline Ya & 67 & 60,90 \\
\hline Tidak & 43 & 39,1 \\
\hline
\end{tabular}


ini dilakukan untuk mengetahui faktor-faktor yang berhubungan dengan perilaku deteksi dini kanker serviks melalui metode Inspeksi Visual Asam Asetat (IVA) pada wanita usia subur di Puskesmas Kecamatan Matraman, Jakarta Timur.

\section{SUBYEK DAN METODE}

Jenis penelitian ini adalah analitik observasional dengan pendekatan Case Control. Populasi dalam penelitian ini adalah wanita usia subur yang berkunjung di poliklinik KIA/ KB di Puskesmas Kecamatan Matraman, Jakarta Timur. Dengan metode quota sampling, terpilih sampel sebenayak 110 wnaita usia subur (WUS). Data terkait variabel independen (umur, pendidikan, pengetahuan, paritas, jenis alat kontrasepsi, jarak pelayanan kesehatan, keterpaparan informasi, dan dukungan suami) dan dependen (perilaku deteksi dini dengan metode IVA) dikumpulkan dengan kuesioner dengan metode wawancara. Analisis data yang digunakan adalah regresi logistik berganda
HASIL

Hasil penelitian menggambarkan bahwa sebagian besar reposnden berusia muda $(65,5 \%)$, memiliki pengetahuan tinggi (70,9\%), memakai alat kontrasepsi hormonal $(57,3 \%)$, jarak tempat layanan terbanyak adalah jarak $(63,6 \%)$, terpapar informasi baik $(55,5 \%)$, mendapat dukungan suami/keluarga $(60,9 \%)$.

Berdasarkan hasil uji bivariat, diperoleh informasi bahwa varaibel yang mempunyai hubungan bermakna (pvalue $<0,05)$ adalah pengetahuan, paritas, jenis alat kontrasepsi, keterpaparan informasi, dan dukungan suami. Nilai hubungan paling kuat ditunjukkan oleh variabel dukungan suami dengan $\mathrm{OR}=11,985$ (95CI: 4,177 - 34,384).

Setelah dikontrol dengan variabel umur, pendidikan, pengetahuan, paritas, alat kontraspesi, dan jarak tempat pelayanan, diperoleh informasi bahwa variabel keterpaparan informasi dan dukungan suami/keluarga berhubungan secara signifikan dengan perilaku deteksi dini kanker serviks metode IVA. Dari

Tabel 2. Nilai Crude Hubungan Variabel Independen dengan Variabel Dependen

\begin{tabular}{|c|c|c|c|c|c|c|}
\hline \multirow{3}{*}{ Variabel } & \multicolumn{4}{|c|}{ Perilaku Deteksi Dini } & \multirow{3}{*}{$\begin{array}{l}\text { Crude OR } \\
(95 \% \text { CI) } \\
\end{array}$} & \multirow{3}{*}{ P Value } \\
\hline & \multicolumn{2}{|c|}{ Tidak Periksa } & \multicolumn{2}{|c|}{ Periksa } & & \\
\hline & $\mathbf{n}$ & $\%$ & $\mathbf{n}$ & $\%$ & & \\
\hline \multicolumn{7}{|l|}{ Umur } \\
\hline Muda & 43 & 59,7 & 29 & 40,3 & 1,2 & \multirow{2}{*}{0.804} \\
\hline Tua & 21 & 55,3 & 17 & 44,7 & $(0,5-2,6)$ & \\
\hline \multicolumn{7}{|l|}{ Pendidikan } \\
\hline Rendah & 18 & 66,7 & 9 & 33,3 & 1,609 & \multirow{2}{*}{0.421} \\
\hline Tinggi & 46 & 55,4 & 37 & 44,6 & $(0,6-3)$, & \\
\hline \multicolumn{7}{|l|}{ Pengetahuan } \\
\hline Rendah & 24 & 75,0 & 8 & 25,0 & 2,850 & \multirow{2}{*}{0.038} \\
\hline Tinggi & 40 & 51,3 & 38 & 48,7 & $(1,141-7,116)$ & \\
\hline \multicolumn{7}{|l|}{ Paritas } \\
\hline Primipara & 32 & 72,7 & 12 & 27,3 & 2,833 & \multirow{2}{*}{0.02} \\
\hline Multipara & 32 & 48,5 & 34 & 51,5 & $(1,247-6,436)$ & \\
\hline \multicolumn{7}{|l|}{ Alat Kontrasepsi } \\
\hline Non Hormonal & 33 & 70,2 & 14 & 29,8 & 2,443 & \multirow{2}{*}{0.044} \\
\hline Hormonal & 31 & 49,2 & 32 & 50,8 & $(1,097-5,397)$ & \\
\hline \multicolumn{7}{|c|}{ Jarak Tempat Pelayanan } \\
\hline Dekat & 46 & 65,7 & 24 & 34,3 & 2,343 & \multirow{2}{*}{0.055} \\
\hline Jauh & 18 & 45,0 & 22 & 55,0 & $(1,058-5,186)$ & \\
\hline \multicolumn{7}{|c|}{ Ketepaparan informasi } \\
\hline Kurang & 41 & 83,7 & 8 & 16,3 & 8,467 & \multirow{2}{*}{0} \\
\hline Baik & 23 & 37,7 & 38 & 62,3 & $(3,383-21,196)$ & \\
\hline \multicolumn{7}{|l|}{ Dukungan suami } \\
\hline Tidak & 38 & 88,4 & 5 & 11,6 & & \multirow{3}{*}{0} \\
\hline Ya & 26 & 38,8 & 41 & 61,2 & 11,985 & \\
\hline Jumlah & 64 & 58,2 & 46 & 41,8 & $(4,177-34,384)$ & \\
\hline
\end{tabular}


Tabel 3. Model Akhir Multivariat yang Mempengaruhi Perilaku Deteksi Dini Kanker Seviks Metode IVA Di Puskesmas Kec. Matraman Tahun 2014

\begin{tabular}{ccc}
\hline Variabel & $\begin{array}{c}\text { Adjusted OR (95\%CI : } \\
\text { Lower-Upper) }\end{array}$ & P Value \\
\hline Keterpaparan informasi & 15.074 & 0.000 \\
Dukungan Suami & $(4.587-49.544)$ & \\
& 21.379 & 0.000 \\
& $(5.444-74.356)$ & \\
\hline
\end{tabular}

kedua variabel tersebut, variabel dukungan suami/keluarga merupakan variabel yang paling dominan dengan OR $=21.379$ (95\%CI : 5,4474,356 ) dan pvalue $=0,00$. Artinya, WUS yang tidak mendapatkan dukungan suami/keluarga berpeluang 21 kali lebih besar untuk tidak melakukan pemeriksaan dini (metode IVA) untuk Kanker Serviks ddibandingkan dengan WUS yang mendapat dukungan suami/keluarga.

\section{DISKUSI}

Deteksi dini kanker serviks dengan metode IVA test adalah metode sederhana pemeriksaan serviks dengan cara melihat langsung serviks dengan memulas serviks dengan larutan asam asetat $3-5 \%$. perubahan warna pada serviks dapat menunjukkan serviks normal (merah homogen) atau lesi pra kanker (bercak putih) (Handayani, dkk, 2012)

Hasil penelitian memaparkan bahwa $41,8 \%$ wanita usia subur melakukan pemeriksaan IVA. Angka ini jauh di bawah target yang ditetapkan Departemen Kesehatan, yaitu $80 \%$. Terdapat beberapa hal yang mempengaruhi ibu dalam deteksi dini kanker serviks, diantaranya adalah kurang informasi tentang IVA, perubahan sosial budaya, dimana ibu bekerja atau kesibukan sosial lainnya, malu untuk memperlihatkan alat kelaminnya, serta tidak siap menerima hasil bila positif kanker.

Hasil penelitian menunjukkan bahwa variabel yang berhubungan signifikan denga perilaku deteksidinikanker serviks dengan metode IVA adalah keterpaparan informasi. Hal ini sejalan dengan penelitian yang dilakukan Rohmawati (2010) dan Sarini (2011) (Rohmawati, 2010; dan Sarini, 2011). Penyampaian informasi yang baik antara petugas kesehatan dengan masyarakat atau antara masyarakat itu sendiri berkontribusi positif terhadap perilaku pemeriksaan deteksi dini kanker serviks. Penyampaian informasi dapat melalui penyuluhan atau pembagian brosur.

Berdasarkan pengamatan, Puskesmas Matraman mempunyai jadwal pemeriksaan IVA yang diadakan seminggu sekali dan biasanya tiap hari rabu. Jadwal tersebut dimanfaatkan oleh petugas kesehatan untuk memberikan informasi tentang deteksi dini kanker serviks metode IVA kepada masyarakat. Walaupun belum terdapat perubahan signifikan, dengan seringnya dilakukan penyuluhan, diharapkan cakupan pelayanan IVA akan meningkat sehingga dapat menekan angka kejadian kanker serviks di wilayah Matraman.

Di samping itu, hasil penelitian menunjukkan bahwa dukungan suami juga berhubungan signifikan dengan perilaku deteksi kanker serviks dengan metode IVA. Hasil penelitian ini sejalan dengan penelitian Purba (Purba, 2011). Peran suami dan keluarga sangat kuat dalam memberikan dukungan bagi ibu untuk melakukan pemeriksaan kesehatan sehingga sangat mempengaruhi status kesehatannya. Suami dan keluarga merupakan orang terdekat dengan WUS dalam berinteraksi dan dalam mengambil keputusan terutama dalam menentukan kemana akan mencari pertolongan atau pengobatan.

\section{KESIMPULAN}

Setelah dikontrol dengan variabel umur, pendidikan, pengetahuan, paritas, alat kontraspesi, dan jarak tempat pelayanan, diperoleh informasi bahwa variabel keterpaparan informasi dan dukungan suami/keluarga berhubungan secara signifikan dengan perilaku deteksi dini kanker serviks metode IVA. Oleh karena itu, agar wanita usia subur melakukan pemeriksaan IVA, maka perlu ditingkatkan frekuensi penyuluhan terkait dengan pemeriksaan dini kanker serviks yang melibatkan suami atau keluarga dari wanita usia subur tersebut. 
36 ARKESMAS, Volume 3, Nomor 1, Juni 2018

\section{DAFTAR PUSTAKA}

Evennet. (2004). Apa yang perlu Anda Ketahui. Jakarta: Arean

Handayani dkk. (2012). Menaklukkan kanker Serviks dan kanker payudara 3 Terapi Alami. Jakarta: PT Agromdia Pustaka

Nuranna, Laila, dkk. (2008). Skrinning Kanker Leher Rahim dengan Metode Inspeksi Visual Asam Asetat (IVA). Dep kes RI.

Purba, E.M. (2011). Faktor-Faktor yang Berhubungan dengan Pemeriksaan Papsmear pada Pasangan Usia Subur (PUS) di Puskesmas Belawan Kota Medan Tahun 2011. Skripsi : Fakultas Kesehatan Masyarakat Universitas Indonesia.

Rasjidi, I. (2010). 100 Questions and asnswer : Kanker pada Wanita. Jakarta : PT Elex Media Komputindo.

Rohmawati, I. (2010). Faktor-Faktor yang Berhubungan Dengan Perilaku Wanita Usia Subur Dalam Deteksi Dini Kanker Serviks Dengan Metode IVA (Inspeksi Visual Dengan Asam Asetat) Di Wilayah Kerja Ngawen I Kabupaten Gunung Kidul Tahun 2011. Skripsi. Jakarta : Fakultas Kesehatan Masyarakat Universitas Indonesia.

Sarini, N.K.M. (2011). Factor-faktor yang Berhubungan dengan Pemeriksaan Pap Smear pada Wanita Usia Subur di Desa Pucung Wilayah Kerja Puskesmas Tejakula II Kecamatan Tejakula Kabupaten Buleleng Bali Tahun 2011. Skipsi, Jakarta : Fakultas Kesehatan Masyarakat Universitas Indonesia. 